\title{
Hydrogeochemical Characteristics and Quality Assessment of Groundwater in University of Science and Technology Port Harcourt
}

\author{
Tubonimi Joseph Kio Ideriah, Udonna Joseph Ikoro \\ Institute of Pollution studies, Rivers State University of Science and Technology Nkpolu Oroworukwo Port Harcourt, Rivers State, Nigeria
}

Email address:

tjkideriah@ymail.com (T. J. K. Ideriah)

\section{To cite this article:}

Tubonimi Joseph Kio Ideriah, Udonna Joseph Ikoro. Hydrogeochemical Characteristics and Quality Assessment of Groundwater in University of Science and Technology Port Harcourt. International Journal of Environmental Monitoring and Analysis.

Vol. 3, No. 4, 2015, pp. 221-232. doi: 10.11648/j.ijema.20150304.14

\begin{abstract}
The quality and suitability of boreholes water quality in the Rivers State University of Science and Technology were assessed for potability and irrigation purposes by analyzing the water for physico-chemical parameters, microbial contents and irrigation indices using standard methods. The results obtained were compared with permissible limits for drinking water provided by World Health Organization and Standard Organization of Nigeria The results showed pH ranged from $4.09-6.77$ at $26.4-30.3^{\circ} \mathrm{C}$, Turbidity $<0.01 \mathrm{NTU}$ in all the samples, Electrical Conductivity $20-407 \mu \mathrm{S} / \mathrm{cm}$, Salinity $<0.01-0.20 \%$ o,TDS $12-274 \mathrm{mg} / \mathrm{l}$, Chloride $<1.0-12.3 \mathrm{mg} / \mathrm{l}$, Sulphate $<1.0-15.5 \mathrm{mg} / \mathrm{l}$, Phosphate $<0.05-1.9 \mathrm{mg} / \mathrm{l}, \mathrm{Nitrate}$ 0.30 - $6.20 \mathrm{mg} / \mathrm{l}$, Total Alkalinity $\left(\right.$ as $\left.\mathrm{CaCO}_{3}\right) 2-8 \mathrm{mg} / \mathrm{l}$, Total Hardness $<0.1-34.6 \mathrm{mg} / \mathrm{l}$, Calcium $<0.08-9.2 \mathrm{mg} / \mathrm{l}$, Magnesium $<0.05$ - $2.8 \mathrm{mg} / \mathrm{l}$, Sodium $<0.01-44.62 \mathrm{mg} / \mathrm{l}$ and Potassium $<0.01-11.88 \mathrm{mg} / \mathrm{l}$. The results of microbial analyses showed Total Heterotrophic Bacteria population ranged from Nil - $3000 \mathrm{cfu} / \mathrm{ml}$, Total Coliform Bacteria 0 - 210 MPN/100ml while Faecal Coliform Bacteria were not present in all the samples. The Groundwater within the University is fresh, soft and has low pH. The water in some parts had high microbial count and therefore not suitable for drinking. The ground water in the area should be regularly monitored and treated to avoid serious pollution problems. The irrigation indices showed the water is suitable for irrigation and other purposes.
\end{abstract}

Keywords: Groundwater Quality, Physicochemical Parameters, Irrigation Indices, Microbial Population, University

\section{Introduction}

The Niger Delta region is one of the largest wetlands in the world. Some rural inhabitants take what they can from the creeks, ponds and rivers. The Federal Ministry of Water Resources says efforts over the past century to develop National water resources have not yielded much. [1] quoted Central Bank of Nigeria statement that "the population of Nigerians with access to potable water rose from $30 \%$ in 1999 to $65 \%$ in $2005 \%$.

Water is an essential requirement for human and industrial developments. It is also used directly and indirectly by many people for several purposes. Water in general plays a critical part in the maintenance of plant and animal life. Owing to the presence of water in cells and body fluids, such as blood, human beings are approximately $60-75 \%$ water [2].

The major sources of water include springs, ponds, streams, rivers, oceans, rain and ground water. The variety of water sources brings in water with different degrees of impurities. The presence of impurities therefore reduces the use to which the water may be deployed. In this study on Rivers State University of Science and Technology (RSUST), it is limited to bore holes.

For potable water, it must be safe for human consumption while the one for irrigation and some industrial processes may not be as pure as that for human consumption. So water must therefore be analyzed to determine its acceptability for the intended purpose. The levels of parameters obtained may be the cause for rejection or acceptance of the sample.

Sources of water for various uses include atmospheric (i.e. rainwater), surface water (i.e. streams, rivers, ponds, lakes and dams) and groundwater (i.e. springs, wells and mono pumps / boreholes). As a result of prevailing conditions connected with some of these sub-water sources; most industrial, governmental and private sectors in urban areas resort to boreholes as water source for their potable and 
various needs [3].

Sources of groundwater contamination or pollution include leachate from landfill / refuse dumpsite, industrial liquid effluent, domestic waste, agricultural waste, salt water intrusion, oil pollution and geological formations [4]. Many wells (i.e. groundwater sources) in the United States of America have been closed because of contamination by various toxic substances [5].

In the Niger Delta, water is mostly abstracted from the aquiferous Benin Formation [6]. In urban and industrial areas; hydrochemistry, geochemistry and processes at solid / liquid interfaces are among the important issues in environmental risk assessment studies in water resources policies [7]. The chemical composition of groundwater is dependent on the geology and the geochemical processes within the aquifer [8], [9].

Thus, water quality analyses are focal and imperative in groundwater investigation by monitoring both the water level (where possible) and trends of the water quality parameters that are influenced by the geological formations and the anthropogenic activities in a given area [10].

The contamination of shallow groundwater sources leading to incidents of water borne diseases like abdominal disorders, typhoid fever, dysentery and urinary track infectious has been reported in some communities [11],[12]. The main objective is to determine, establish and document the current status of boreholes water quality on the University campus

Port Harcourt, with population well over 1 million lies within latitudes $4^{\circ} 43^{\prime} 07^{\prime \prime}$ and $4^{\circ} 54^{\prime} 32^{\prime \prime} \mathrm{N}$ and longitudes $6^{\circ}$ $56^{\prime} 04^{\prime \prime}$ and $7^{\circ} 03^{\prime} 20^{\prime \prime} \mathrm{E}$ with a mean annual rainfall of over $2000 \mathrm{~mm}$ and mean annual temperature of $29^{\circ} \mathrm{C}$ [13]. The study area Rivers State University of Science and Technology (Fig. 1.1) is located within Port Harcourt metropolis in the Niger Delta sedimentary basin of Nigeria. Port Harcourt is covered on the surface by the Benin Formation which is otherwise called the Coastal Plain Sands. The Benin Formation is Miocene to Recent in age [14]. The domination of loose sands in the Benin Formation makes the ground in Port Harcourt porous and permeable to wastes on the soil surface. This is because during the rainy season, rainwater will cause leachates from the wastes to percolate downwards and pollute the groundwater over time.

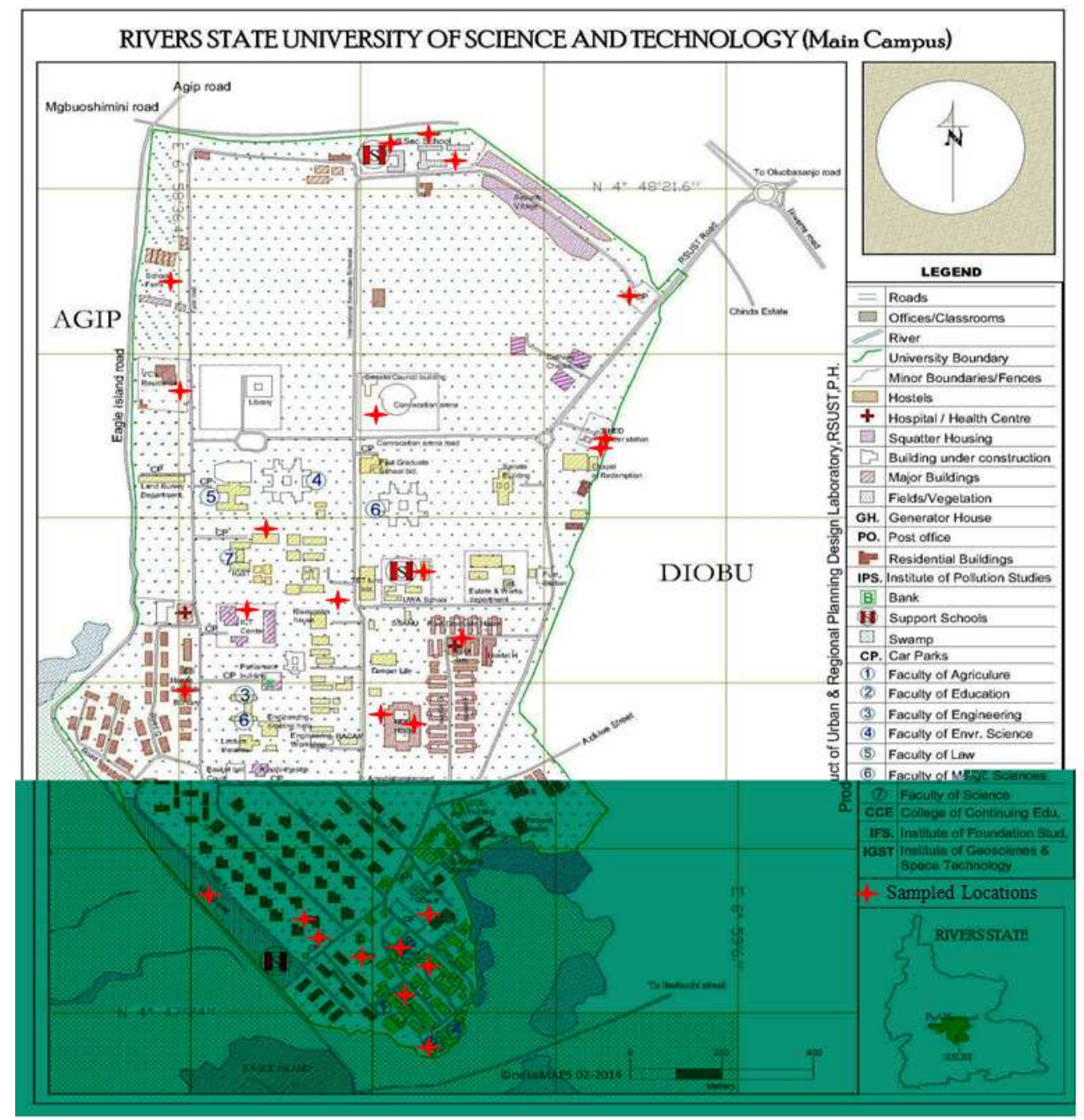

Source: Urban \& Regional Planning Dept. RSUST, P.H.

Figure 1. Map of RSUST showing the sampling stations. 
The ground water level, measured from newly drilled boreholes show that water levels are close to the surface, commonly between $3.05-9.14$ metres. For example, the water level at East - West (Nkpolu, Rumuigbo) is 3.05metres but about 6.10metres at Eneka, etc. [15].

\section{Materials and Methods}

\subsection{Sample Collection}

Samples for physico-chemical analysis were collected in 1.5-litre plastic bottles while those for microbiology were collected in sterile McCartney bottle. All the samples were preserved in iced cool box and transported to the laboratory for analyses. Table 1 shows the sampling stations and GPS Co-ordinates taken with a hand held GPS by Garmin.

Table 1. Sampling Locations and their GPS Co-ordinates.

\begin{tabular}{|c|c|c|c|}
\hline No. & Station & GPS (Latitude) N & GPS (Longitude) E \\
\hline 1 & RSUST Main BH & $4^{\circ} 43^{\prime} 17.70^{\prime \prime}$ & $7^{\circ} 12^{\prime} 11.88^{\prime \prime}$ \\
\hline 2 & Road B Bungalow 1 & $4^{\circ} 40^{\prime} 08.16^{\prime \prime}$ & $7^{\circ} 13^{\prime} 17.94^{\prime \prime}$ \\
\hline 3 & Sick Bay & $4^{\circ} 46^{\prime} 42.84^{\prime \prime}$ & $7^{\circ} 09^{\prime} 21.66^{\prime \prime}$ \\
\hline 4 & Biological Sciences & $4^{\circ} 44^{\prime} 47.52^{\prime \prime}$ & $7^{\circ} 04^{\prime} 51.96^{\prime \prime}$ \\
\hline 5 & IPS Lab & $4^{\circ} 50^{\prime} 42.66^{\prime \prime}$ & $7^{\circ} 03^{\prime} 53.88^{\prime \prime}$ \\
\hline 6 & Hostel E & $4^{\circ} 51^{\prime} 25.38^{\prime \prime}$ & $7^{\circ} 03^{\prime} 25.98^{\prime \prime}$ \\
\hline 7 & VC's Office & $4^{\circ} 44^{\prime} 46.26^{\prime \prime}$ & $7^{\circ} 02^{\prime} 43.38^{\prime \prime}$ \\
\hline 8 & DVC's Office & $4^{\circ} 43^{\prime} 00.72^{\prime \prime}$ & $7^{\circ} 15^{\prime} 09.06^{\prime \prime}$ \\
\hline 9 & Fisheries Aq & $4^{\circ} 39^{\prime} 54.48^{\prime \prime}$ & $7^{\circ} 22^{\prime} 24.48^{\prime \prime}$ \\
\hline 10 & Inst. of Education & $4^{\circ} 41^{\prime} 02.88^{\prime \prime}$ & $7^{\circ} 18^{\prime} 16.50^{\prime \prime}$ \\
\hline 11 & Staff School & $4^{\circ} 44^{\prime} 03.12^{\prime \prime}$ & $6^{\circ} 46^{\prime} 19.98^{\prime \prime}$ \\
\hline 12 & NDDC Hostel 1 & $4^{\circ} 44^{\prime} 45.18^{\prime \prime}$ & $6^{\circ} 45^{\prime} 58.62^{\prime \prime}$ \\
\hline 13 & NDDC Hostel 2 & $4^{\circ} 44^{\prime} 17.16^{\prime \prime}$ & $6^{\circ} 51^{\prime} 43.02^{\prime \prime}$ \\
\hline 14 & Health Services & $4^{\circ} 28^{\prime} 53.64^{\prime \prime}$ & $7^{\circ} 25^{\prime} 22.74^{\prime \prime}$ \\
\hline 15 & ICT & $4^{\circ} 26^{\prime} 42.06^{\prime \prime}$ & $7^{\circ} 10^{\prime} 01.68^{\prime \prime}$ \\
\hline 16 & Med Lab Sciences & $4^{\circ} 53^{\prime} 31.26^{\prime \prime}$ & $7^{\circ} 07^{\prime} 42.42^{\prime \prime}$ \\
\hline 17 & UWA Day Care & $4^{\circ} 57^{\prime} 29.70^{\prime \prime}$ & $6^{\circ} 35^{\prime} 33.24^{\prime \prime}$ \\
\hline 18 & Chapel 1 & $4^{\circ} 56^{\prime} 33.42^{\prime \prime}$ & $6^{\circ} 35^{\prime} 14.82^{\prime \prime}$ \\
\hline 19 & Chapel 2 & $4^{\circ} 30^{\prime} 53.40^{\prime \prime}$ & $7^{\circ} 32^{\prime} 29.16^{\prime \prime}$ \\
\hline 20 & Main Gate Park & $5^{\circ} 06^{\prime} 07.47^{\prime \prime}$ & $7^{\circ} 07^{\prime} 48.32^{\prime \prime}$ \\
\hline 21 & Council Unit & $5^{\circ} 05^{\prime} 47.90^{\prime \prime}$ & $6^{\circ} 49^{\prime} 10.88^{\prime \prime}$ \\
\hline 22 & ISS 1 & $5^{\circ} 10^{\prime} 56.04^{\prime \prime}$ & $6^{\circ} 39^{\prime} 57.21^{\prime \prime}$ \\
\hline 23 & ISS 2 & $5^{\circ} 09^{\prime} 12.30^{\prime \prime}$ & $6^{\circ} 38^{\prime} 03.86^{\prime \prime}$ \\
\hline 24 & ISS VP & $5^{\circ} 04^{\prime} 22.06^{\prime \prime}$ & $6^{\circ} 39^{\prime} 06.98^{\prime \prime}$ \\
\hline 25 & VC's Lodge & $5^{\circ} 04^{\prime} 25.93 "$ & $6^{\circ} 33^{\prime} 46.62^{\prime \prime}$ \\
\hline 26 & Agric. Farm & $5^{\circ} 04^{\prime} 00.16^{\prime \prime}$ & $6^{\circ} 26^{\prime} 29.61^{\prime \prime}$ \\
\hline
\end{tabular}

\subsection{Field Measurements}

Some in situ measurements were taken in the field for $\mathrm{pH}$, Temperature, Conductivity, Salinity and Total Dissolved Solids using Extech DO700 meter calibrated with buffer $\mathrm{pH}$ 4.0, 7.0 and 10.0 as well as $1413 \mu \mathrm{S} / \mathrm{cm}$ conductivity solution.

\subsection{Laboratory Analyses}

Except otherwise stated, the laboratory methodologies used were from Standard Methods for the Examination of Water and Wastewater by American Public Health Association [16] and American Society for Testing \& Material [17].

Total Alkalinity was determined by titration with $0.02 \mathrm{~N}$ $\mathrm{H}_{2} \mathrm{SO}_{4}$ - using methyl orange indicator [16]. Chloride was determined titrimetrically by the Argentometric method in the presence of potassium chromate as the indicator. Phosphate was determined by the Ammonium Molybdate $\left.\left(\mathrm{NH}_{4}\right)_{2} \mathrm{MoO}_{4}\right)$ method. Nitrate was determined using the Brucine Method [16]. Sulphate was determined by Turbidimetric method [16].

$100 \mathrm{mls}$ of water sample was taken. $2 \mathrm{mls}$ of buffer solution was added along with a pinch of Eriochrome black $\mathrm{T}$ indicator and titrated with 0.0IM EDTA until a blue colour was observed.

Sodium and Aluminium were determined by direct aspiration into Flame Atomic Emission Photometer.

\subsection{Microbiology}

The ten-fold serial dilution was used to obtain appropriate dilutions of the samples. Aliquots of the required dilutions were plated in duplicates onto the surface of dried sterile nutrient agar plates for total heterotrophic bacteria. In the case of total/faecal coliform bacteria, the most probable number (MPN) technique was employed for estimation of their numbers in water. Appropriate volumes of undiluted water samples were inoculated into test tubes of MacConkey broth containing Durham tubes. All inoculated media were incubated at $37^{\circ} \mathrm{C}$ for 24 hours except for faecal coliform bacteria which was incubated at $44^{\circ} \mathrm{C}$ [16].

\section{Results}

The range, mean and standard deviation values of the physico-chemical as well as microbiological properties of groundwater samples within the Rivers State University of Science and Technology for July and September 2013 are shown in Table 2. Also contained in the Table 2 are Standard Organization of Nigeria (SON) limits for drinking water and World Health Organization (WHO) standards [18],[19].

\subsection{Physico-Chemical Parameters pH}

The ground water $\mathrm{pH}$ ranged from $4.09-6.77$ with a mean of $4.93 \pm 0.58$. In July all the samples $(100 \%)$ were in the range $4.30-5.40$ while in September $12.5 \%$ of the samples were within $6.73-6.77$ range whereas $87.5 \%$ of the samples had $\mathrm{pH}$ ranging from 4.09-6.39. The lowest $\mathrm{pH} 4.30$ came from ISS2 in July while in September $\mathrm{pH} 4.09$ was obtained at the Main Gate Motor Park (Fig. 2). 
Table 2. Ranges and Means of RSUST Groundwater in July and September 2013.

\begin{tabular}{|c|c|c|c|c|c|c|c|}
\hline No. & Parameters & Min & Max & Mean & \pm SD & SON (2007) & WHO (2006) \\
\hline 1 & $\mathrm{pH}$ & 4.09 & 6.77 & 4.93 & 0.58 & $6.5-8.5$ & $6.5-8.5$ \\
\hline 2 & Temperature $\left({ }^{\circ} \mathrm{C}\right)$ & 26.4 & 30.3 & 28.3 & 1.2 & NS & NS \\
\hline 3 & Conductivity $(\mu \mathrm{S} / \mathrm{cm})$ & 20 & 407 & 103 & 102 & 1000 & 1200 \\
\hline 4 & Salinity (\%o) & $<0.01$ & 0.2 & 0.03 & 0.06 & NS & NS \\
\hline 5 & TDS (mg/l) & 12 & 274 & 67 & 67 & 500 & 600 \\
\hline 6 & Turbidity (NTU) & $<0.05$ & $<0.05$ & $<0.05$ & $<0.05$ & 5 & 5 \\
\hline 7 & Chloride, $\mathrm{Cl}^{-}(\mathrm{mg} / \mathrm{l})$ & $<1.0$ & 12.3 & 2.9 & 2.8 & 250 & 250 \\
\hline 9 & Phosphate, $\mathrm{PO}_{4}^{-3}(\mathrm{mg} / \mathrm{l})$ & $<0.05$ & 1.90 & 0.05 & 0.29 & NS & NS \\
\hline 10 & Nitrate, $\mathrm{NO}_{3}^{-}(\mathrm{mg} / \mathrm{l})$ & 0.30 & 6.20 & 2.65 & 1.32 & 50 & 50 \\
\hline 11 & Alkalinity $\left(\left(\mathrm{mg} / \mathrm{l}\right.\right.$ as $\left.\mathrm{CaCO}_{3}\right)$ & 2 & 8 & 3.8 & 1.8 & 100 & 100 \\
\hline 12 & Carbonate, $\mathrm{CO}_{3}^{-2}(\mathrm{mg} / \mathrm{l})$ & 0 & 0 & 0 & 0 & NS & NS \\
\hline 13 & Bicarbonate, $\mathrm{HCO}_{3}^{-}(\mathrm{mg} / \mathrm{l})$ & 4 & 16 & 7.5 & 3.7 & NS & NS \\
\hline 14 & Hardness (mg/l as $\left.\mathrm{CaCO}_{3}\right)$ & $<0.1$ & 34.6 & 8.0 & 7.8 & 150 & 200 \\
\hline 15 & Calcium, $\mathrm{Ca}^{+2}(\mathrm{mg} / \mathrm{l})$ & $<0.08$ & 9.2 & 1.7 & 1.9 & NS & NS \\
\hline 16 & Magnesium, $\mathrm{Mg}^{+2}(\mathrm{mg} / \mathrm{l})$ & $<0.05$ & 2.8 & 0.9 & 0.8 & 0.2 & NS \\
\hline 18 & Potassium, $\mathrm{K}^{+}(\mathrm{mg} / \mathrm{l})$ & $<0.01$ & 11.88 & 1.50 & 2.64 & NS & NS \\
\hline 19 & THB (cfu/ml) & Nil & 3000 & 109 & 570 & NS & $<100$ \\
\hline 20 & TCB (MPN/100ml) & Nil & 210 & 8.6 & 43.6 & 10 & $0-2$ \\
\hline 21 & FCB (MPN/100ml) & Nil & Nil & Nil & Nil & 0 & 0 \\
\hline
\end{tabular}

Note: $<0.05=$ Less than detection limit; NS $=$ Not Specified.

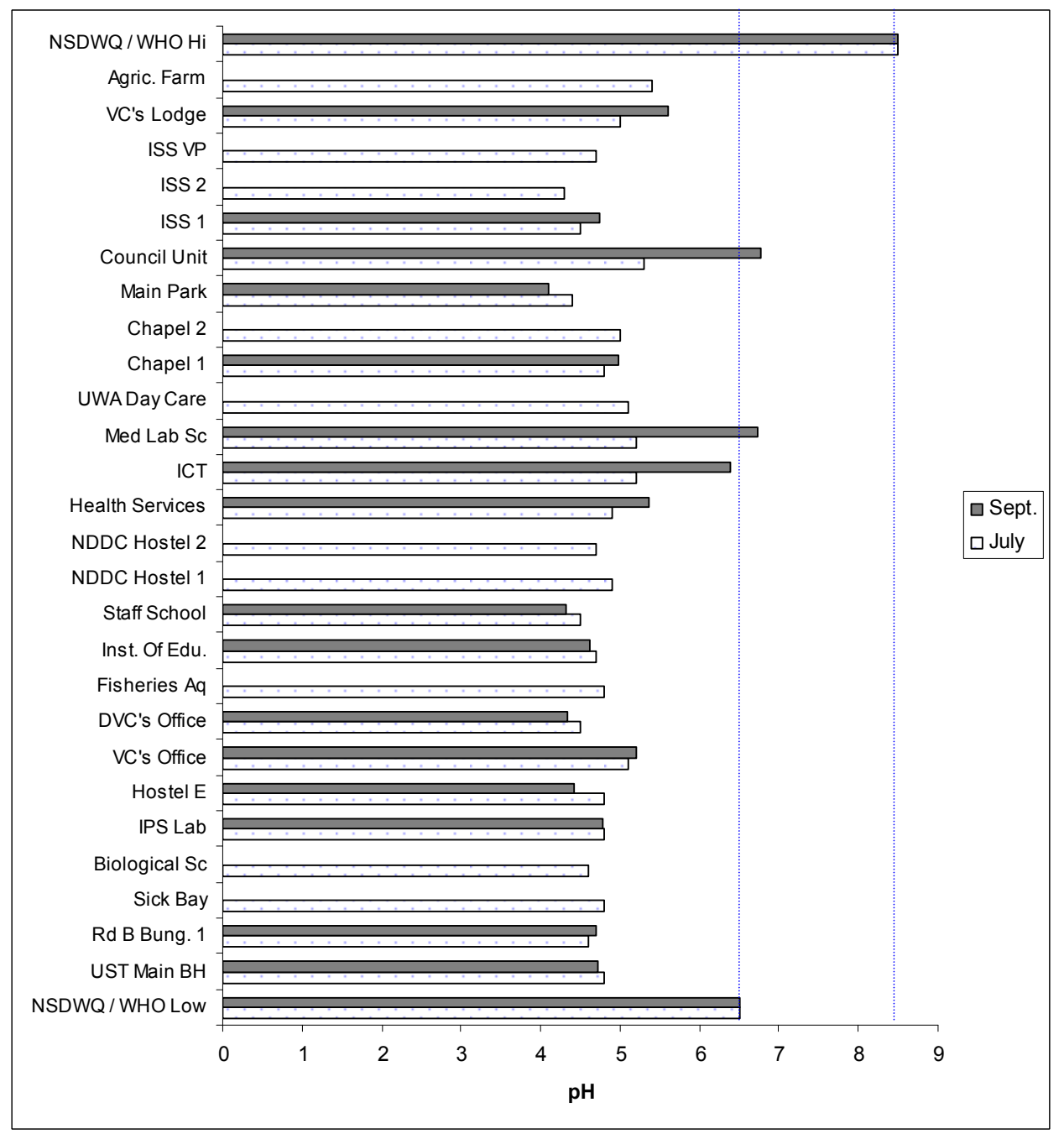

Figure 2. The pH of groundwater in RSUST in July and September 2013. 


\subsection{Temperature and Turbidity}

Groundwater Temperature ranged from $26.4-30.3^{\circ} \mathrm{C}$ with a mean of $28.3 \pm 1.2^{\circ} \mathrm{C}$. Turbidity was $<0.05 \mathrm{NTU}$ in all the samples.

\subsection{Conductivity, Salinity and TDS}

Conductivity values ranged from $20-407 \mu \mathrm{S} / \mathrm{cm}$ with a mean of $103 \pm 102 \mu \mathrm{S} / \mathrm{cm}$. Salinity values ranged from $<0.01-0.20 \%$ o with a mean of $0.03 \pm 0.06 \%$. Similarly, TDS values varied from $12-274 \mathrm{mg} / \mathrm{l}$ with a mean of $67 \pm 67 \mathrm{mg} / \mathrm{l}$ (Fig. 3 ).

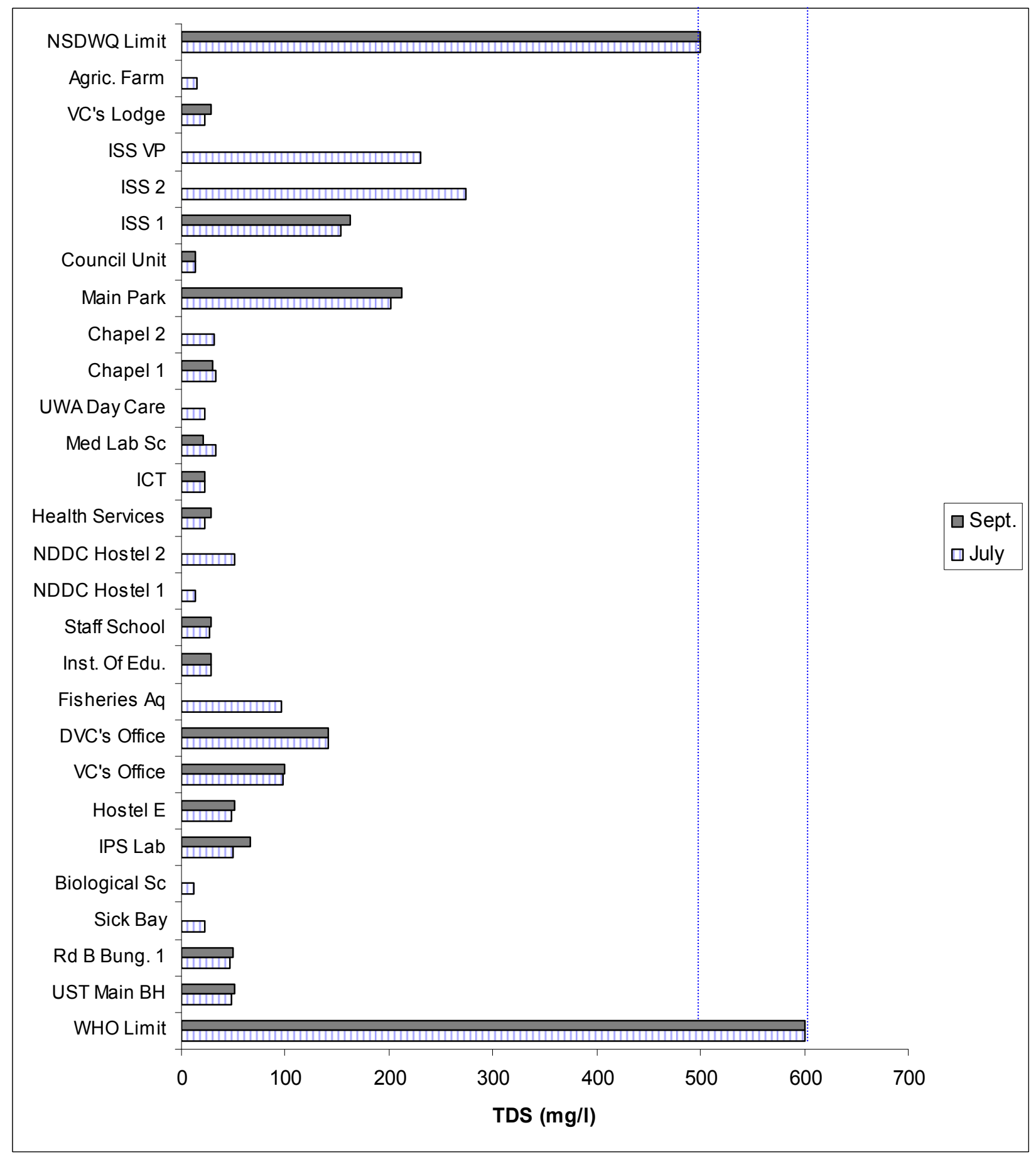

Figure 3. TDS levels of RSUST groundwater in July and September 2013.

The correlation existing among the parameters measured are shown in Table 3. TDS correlated strongly with the
Conductivity, Salinity, Chloride, Hardness, Calcium, Magnesium, Sodium and Potassium. 


\subsection{Chloride, Sulphate, Phosphate and Nitrate}

Chloride concentrations ranged from $<1.0$ to $12.3 \mathrm{mg} / 1$ with a mean of $2.9 \pm 2.6 \mathrm{mg} / \mathrm{l}$. Similarly, Sulphate concentrations varied from $<1.0-15.5 \mathrm{mg} / 1$ with a mean of $2.4 \pm 3.0 \mathrm{mg} / \mathrm{l}$. Phosphate concentrations ranged from $<0.05-$ $1.9 \mathrm{mg} / \mathrm{l}$ with a mean of $0.05 \pm 0.29 \mathrm{mg} / \mathrm{l}$ while the nitrate concentrations varied from $0.30-6.20 \mathrm{mg} / \mathrm{l}$ with a mean of $2.65 \pm 1.32 \mathrm{mg} / \mathrm{l}$.

\subsection{Total Alkalinity and Hardness}

Total Alkalinity values $\left(\right.$ as $\mathrm{CaCO}_{3}$ ) were from $2-8 \mathrm{mg} / 1$ with a mean of $3.8 \pm 1.8 \mathrm{mg} / 1$ whereas the Hardness values varied from $<0.1-34.6 \mathrm{mg} / 1$ with a mean of $8.0 \pm 7.8 \mathrm{mg} / 1$.

\subsection{Calcium and Magnesium}

The Calcium concentrations ranged from $<0.08-9.2$ $\mathrm{mg} / 1$ with a mean of $1.7 \pm 1.9 \mathrm{mg} / \mathrm{l}$ whereas Magnesium values varied from $<0.05-2.8 \mathrm{mg} / 1$ with a mean of $0.9 \pm 0.8$ $\mathrm{mg} / \mathrm{l}$.

\subsection{Sodium and Potassium}

Sodium concentrations ranged from $<0.01-44.62 \mathrm{mg} / 1$ with a mean of $11.21 \pm 13.2 \mathrm{mg} / \mathrm{l}$ whereas Potassium concentrations ranged from $<0.01-11.88 \mathrm{mg} / \mathrm{l}$ with a mean of $1.50 \pm 2.64 \mathrm{mg} / 1$.

Table 3. Correlation matrix of parameters measured in RSUST groundwater.

\begin{tabular}{|c|c|c|c|c|c|c|c|c|c|c|c|c|c|c|c|c|c|c|c|c|c|}
\hline & pH & Temp & Cond & Sal & TDS & Turb & Cl & $\mathrm{SO}_{4}$ & $\mathrm{PO}_{4}$ & $\mathrm{NO}_{3}$ & Alk. & $\mathrm{CO}_{3}$ & $\begin{array}{l}\mathrm{HCO} \\
\end{array}$ & Hard & $\mathrm{Ca}$ & Mg & $\mathrm{Na}$ & $\mathbf{K}$ & THB & TCB & FCB \\
\hline $\mathrm{pH}$ & 1 & & & & & & & & & & & & & & & & & & & & \\
\hline $\begin{array}{l}\text { Tem } \\
\mathrm{p}\end{array}$ & 0.098 & 1 & & & & & & & & & & & & & & & & & & & \\
\hline Cond & -0.462 & 0.041 & 1 & & & & & & & & & & & & & & & & & & \\
\hline Sal & -0.373 & 0.042 & 0.958 & 1 & & & & & & & & & & & & & & & & & \\
\hline TDS & -0.458 & 0.038 & 0.998 & 0.962 & 1 & & & & & & & & & & & & & & & & \\
\hline Turb. & $\begin{array}{l}\text { DIV/0 } \\
!\end{array}$ & $\begin{array}{l}\mathrm{DIV} / 0 \\
!\end{array}$ & $\begin{array}{l}\mathrm{DIV} / 0 \\
!\end{array}$ & $\begin{array}{l}\text { DIV/0 } \\
!\end{array}$ & $\begin{array}{l}\text { DIV/0 } \\
!\end{array}$ & 1 & & & & & & & & & & & & & & & \\
\hline $\mathrm{Cl}$ & -0.402 & 0.272 & 0.780 & 0.769 & 0.766 & $\begin{array}{l}\text { DIV/0 } \\
!\end{array}$ & 1 & & & & & & & & & & & & & & \\
\hline $\mathrm{SO}_{4}$ & -0.261 & -0.134 & 0.448 & 0.477 & 0.454 & $\begin{array}{l}\text { DIV/0 } \\
!\end{array}$ & 0.208 & 1 & & & & & & & & & & & & & \\
\hline $\mathrm{PO}_{4}$ & -0.009 & -0.176 & -0.107 & -0.089 & -0.105 & $\begin{array}{l}\text { DIV/0 } \\
!\end{array}$ & -0.096 & -0.024 & & & & & & & & & & & & & \\
\hline $\mathrm{NO}_{3}$ & -0.251 & 0.357 & 0.437 & 0.366 & 0.413 & $\begin{array}{l}\mathrm{DIV} / 0 \\
!\end{array}$ & 0.583 & 0.007 & -0.113 & & & & & & & & & & & & \\
\hline Alk. & 0.364 & 0.395 & -0.162 & -0.081 & -0.177 & $\begin{array}{l}\text { DIV/0 } \\
!\end{array}$ & 0.001 & -0.055 & 0.021 & 0.323 & 1 & & & & & & & & & & \\
\hline $\mathrm{CO}_{3}$ & $\begin{array}{l}\mathrm{DIV} / 0 \\
!\end{array}$ & $\begin{array}{l}\text { DIV/0 } \\
!\end{array}$ & $\begin{array}{l}\text { DIV/0 } \\
!\end{array}$ & $\begin{array}{l}\text { DIV/0 } \\
!\end{array}$ & $\begin{array}{l}\text { DIV/0 } \\
!\end{array}$ & $\begin{array}{l}\text { DIV/0 } \\
!\end{array}$ & $\begin{array}{l}\text { DIV/0 } \\
!\end{array}$ & $\begin{array}{l}\text { DIV/0 } \\
!\end{array}$ & $\begin{array}{l}\text { DIV/0 } \\
!\end{array}$ & $\begin{array}{l}\text { DIV/0 } \\
!\end{array}$ & $\begin{array}{l}\text { DIV/0 } \\
!\end{array}$ & 1 & & & & & & & & & \\
\hline${ }_{3} \mathrm{HCO}$ & 0.364 & 0.395 & -0.162 & -0.081 & -0.177 & $\begin{array}{l}\text { DIV/0 } \\
!\end{array}$ & 0.001 & -0.055 & 0.021 & 0.323 & 1 & $\begin{array}{l}\text { DIV/0 } \\
!\end{array}$ & 1 & & & & & & & & \\
\hline Hard & -0.380 & 0.135 & 0.662 & 0.625 & 0.662 & $\begin{array}{l}\text { DIV/0 } \\
!\end{array}$ & 0.669 & 0.662 & -0.005 & 0.301 & -0.154 & $\begin{array}{l}\text { DIV/0 } \\
!\end{array}$ & -0.154 & & & & & & & & \\
\hline $\mathrm{Ca}$ & -0.341 & 0.178 & 0.578 & 0.553 & 0.578 & $\begin{array}{l}\text { DIV/0 } \\
!\end{array}$ & 0.644 & 0.646 & -0.014 & 0.310 & -0.091 & $\begin{array}{l}\text { DIV/0 } \\
!\end{array}$ & -0.091 & 0.971 & 1 & & & & & & \\
\hline $\mathrm{Mg}$ & -0.401 & 0.068 & 0.733 & 0.682 & 0.734 & $\begin{array}{l}\text { DIV/0 } \\
!\end{array}$ & 0.654 & 0.612 & 0.000 & 0.278 & -0.215 & $\begin{array}{l}\text { DIV/0 } \\
!\end{array}$ & -0.215 & 0.937 & 0.827 & 1 & & & & & \\
\hline $\mathrm{Na}$ & -0.459 & 0.014 & 0.953 & 0.897 & 0.953 & $\begin{array}{l}\text { DIV/0 } \\
!\end{array}$ & 0.722 & 0.321 & -0.098 & 0.415 & -0.230 & $\begin{array}{l}\text { DIV/0 } \\
!\end{array}$ & -0.230 & 0.559 & 0.487 & 0.627 & 1 & & & & \\
\hline K & -0.371 & 0.151 & 0.761 & 0.714 & 0.762 & $\begin{array}{l}\text { DIV/0 } \\
!\end{array}$ & 0.736 & 0.213 & -0.065 & 0.510 & -0.229 & $\begin{array}{l}\text { DIV/0 } \\
!\end{array}$ & -0.229 & 0.589 & 0.556 & 0.595 & 0.798 & 1 & & & \\
\hline THB & -0.121 & 0.227 & -0.113 & -0.103 & -0.102 & $\begin{array}{l}\text { DIV/0 } \\
!\end{array}$ & -0.139 & -0.158 & -0.053 & 0.057 & 0.034 & $\begin{array}{l}\text { DIV/0 } \\
!\end{array}$ & 0.034 & -0.078 & -0.071 & -0.061 & -0.118 & -0.146 & & & \\
\hline TCB & -0.121 & 0.374 & -0.137 & -0.130 & -0.132 & $\begin{array}{l}\text { DIV/0 } \\
!\end{array}$ & -0.146 & -0.121 & -0.043 & -0.016 & -0.089 & $\begin{array}{l}\text { DIV/0 } \\
!\end{array}$ & -0.089 & -0.055 & -0.053 & -0.048 & -0.140 & -0.141 & 0.733 & 1 & \\
\hline FCB & $\begin{array}{l}\text { DIV/0 } \\
!\end{array}$ & $\begin{array}{l}\text { DIV/0 } \\
! \\
\end{array}$ & $\begin{array}{l}\text { DIV/0 } \\
!\end{array}$ & $\begin{array}{l}\text { DIV/0 } \\
!\end{array}$ & $\begin{array}{l}\text { DIV/0 } \\
!\end{array}$ & $\begin{array}{l}\text { DIV/0 } \\
!\end{array}$ & $\begin{array}{l}\text { DIV/0 } \\
!\end{array}$ & $\begin{array}{l}\text { DIV/0 } \\
!\end{array}$ & $\begin{array}{l}\text { DIV/0 } \\
!\end{array}$ & $\begin{array}{l}\text { DIV/0 } \\
!\end{array}$ & $\begin{array}{l}\text { DIV/0 } \\
!\end{array}$ & $\begin{array}{l}\text { DIV/0 } \\
! \\
\end{array}$ & $\begin{array}{l}\text { DIV/0 } \\
! \\
\end{array}$ & $\begin{array}{l}\text { DIV/0 } \\
! \\
\end{array}$ & $\begin{array}{l}\text { DIV/0 } \\
! \\
\end{array}$ & $\begin{array}{l}\text { DIV/0 } \\
!\end{array}$ & DIV/0! & $\begin{array}{l}\text { DIV/0 } \\
! \\
\end{array}$ & $\begin{array}{l}\text { DIV/0 } \\
!\end{array}$ & $\begin{array}{l}\text { DIV/0 } \\
!\end{array}$ & 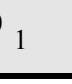 \\
\hline
\end{tabular}

Table 4 contains the July and September means of the parameters required in the characterization of RSUST groundwater. A plot of these hydro-geochemical data on the Piper diagram [20] is shown in Fig. 4. 
Table 4. Mean values of the hydro-geochemical data of RSUST groundwater.

\begin{tabular}{|c|c|c|c|c|c|c|c|c|c|c|}
\hline & & $\mathrm{Ca}^{+2}$ & $\mathrm{Mg}^{+2}$ & $\mathrm{Na}^{+}$ & $\mathbf{K}^{+}$ & $\mathrm{CO}_{3}{ }^{-2}$ & $\mathrm{HCO}_{3}^{-}$ & $\mathrm{Cl}^{-}$ & $\mathrm{SO}_{4}{ }^{-2}$ & TDS \\
\hline S/No & Station & $\mathrm{mg} / \mathrm{l}$ & $\mathrm{mg} / \mathrm{l}$ & $\mathrm{mg} / \mathrm{l}$ & $\mathrm{mg} / 1$ & $\mathrm{mg} / \mathrm{l}$ & $\mathrm{mg} / 1$ & $\mathrm{mg} / \mathrm{l}$ & $\mathrm{mg} / \mathrm{l}$ & $\mathrm{mg} / 1$ \\
\hline 1 & UST Main BH & 1.5 & 1.4 & 13.49 & 2.33 & 0 & 6 & 2.8 & 0.9 & 49.5 \\
\hline 2 & Rd B Bung. 1 & 1.5 & 0.9 & 8.73 & 0.71 & 0 & 6 & 2.6 & 1.5 & 48.7 \\
\hline 3 & Sick Bay & 1.5 & 0.9 & 3.36 & 0.41 & 0 & 8 & 2.4 & 2.1 & 22 \\
\hline 4 & Biological Sc & 0.0 & 0.0 & 1.58 & 0.21 & 0 & 8 & 0.0 & 1.9 & 12 \\
\hline 5 & IPS Lab & 1.15 & 0.7 & 13.50 & 2.12 & 0 & 10 & 4.6 & 0.9 & 74.5 \\
\hline 6 & Hostel E & 3.8 & 1.85 & 13.60 & 1.32 & 0 & 12 & 4.9 & 5.9 & 95 \\
\hline 7 & VC's Office & 1.15 & 0.7 & 5.95 & 0.41 & 0 & 8 & 3.7 & 1.4 & 63.5 \\
\hline 8 & DVC's Office & 4.6 & 1.4 & 11.11 & 0.91 & 0 & 8 & 3.8 & 7.75 & 85.5 \\
\hline 9 & Fisheries Aq & 1.5 & 0.9 & 18.26 & 1.62 & 0 & 8 & 4.4 & 4.6 & 97 \\
\hline 10 & Inst. of Edu. & 1.15 & 0.7 & 2.57 & 0.01 & 0 & 6 & 1.4 & 0.9 & 25 \\
\hline 11 & Staff School & 0 & 0 & 2.57 & 0.21 & 0 & 10 & 1.2 & 0.7 & 24 \\
\hline 12 & NDDC Hostel 1 & 0.0 & 0.0 & 0.78 & 0.21 & 0 & 4 & 0.0 & 2.2 & 13 \\
\hline 13 & NDDC Hostel 2 & 1.5 & 0.9 & 6.34 & 3.03 & 0 & 4 & 1.0 & 2.8 & 51 \\
\hline 14 & Health Serv. & 1.5 & 0.9 & 1.68 & 0.21 & 0 & 8 & 1.1 & 1.55 & 18 \\
\hline 15 & ICT & 1.15 & 0.7 & 20.32 & 1.32 & 0 & 6 & 4.4 & 1.35 & 92.5 \\
\hline 16 & Med Lab Sc & 1.55 & 0.45 & 3.56 & 0.11 & 0 & 8 & 1.5 & 1.85 & 30.5 \\
\hline 17 & UWA Day Care & 0.0 & 0.0 & 3.56 & 0.61 & 0 & 8 & 1.4 & 2.1 & 22 \\
\hline 18 & Chapel 1 & 0.75 & 0.45 & 2.38 & 0 & 0 & 2 & 0.85 & 1.05 & 16.5 \\
\hline 19 & Chapel 2 & 1.5 & 0.9 & 4.75 & 0.00 & 0 & 4 & 1.2 & 2.6 & 32 \\
\hline 20 & Main Park & 3.85 & 0.95 & 22.31 & 5.94 & 0 & 2 & 5.15 & 1.2 & 101 \\
\hline 21 & Council Unit & 0.75 & 0.45 & 0 & 0 & 0 & 4 & 0.5 & 1.35 & 7 \\
\hline 22 & ISS 1 & 0.75 & 0.45 & 18.84 & 1.31 & 0 & 2 & 0.7 & 1.2 & 76.5 \\
\hline 23 & ISS 2 & 3.1 & 2.8 & 43.63 & 3.03 & 0 & 4 & 8.1 & 2.7 & 274 \\
\hline 24 & ISS VP & 1.5 & 1.9 & 39.66 & 6.45 & 0 & 4 & 1.0 & 11.3 & 230 \\
\hline 25 & VC's Lodge & 0 & 0 & 2.28 & 0.11 & 0 & 4 & 1.35 & 1.25 & 11 \\
\hline 26 & Agric. Farm & 1.5 & 0.9 & 1.77 & 0.21 & 0 & 8 & 1.2 & 2.0 & 15 \\
\hline
\end{tabular}

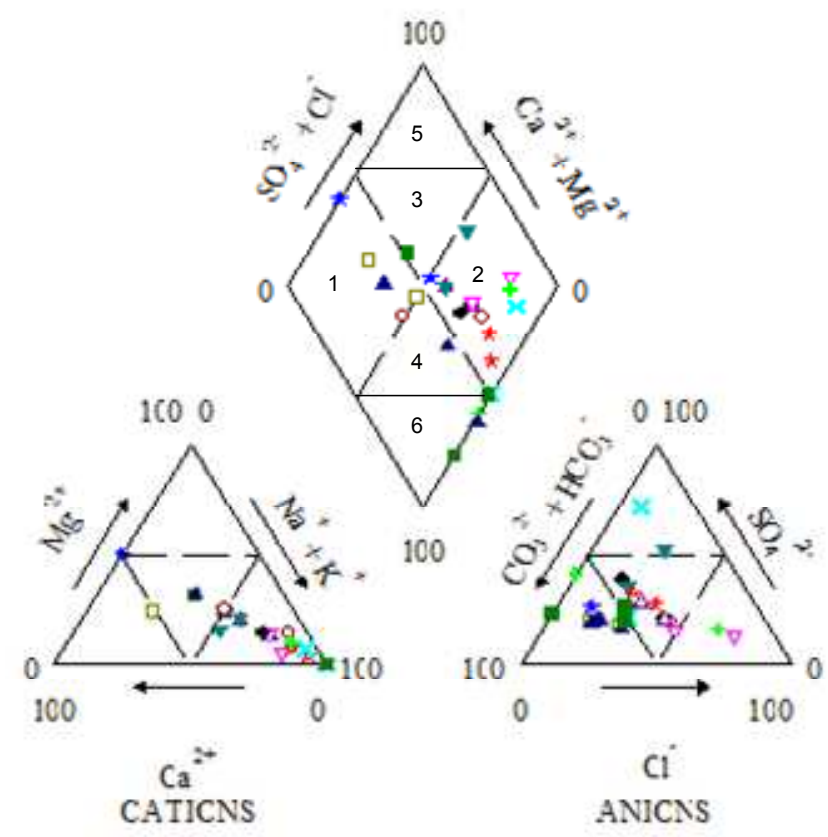

Figure 4. Piper tri-linear diagram showing groundwater classification.

Graphical presentation showing order of occurrence of the major anions $\left(\mathrm{HCO}_{3}^{-}, \mathrm{Cl}^{-}, \mathrm{SO}_{4}{ }^{2-}\right.$ and $\left.\mathrm{CO}_{3}{ }^{2-}\right)$ and the corresponding major cations ( $\mathrm{Na}, \mathrm{Ca}, \mathrm{K}$ and $\mathrm{Mg}$ ) are shown in the Pie chart (Fig. 5).

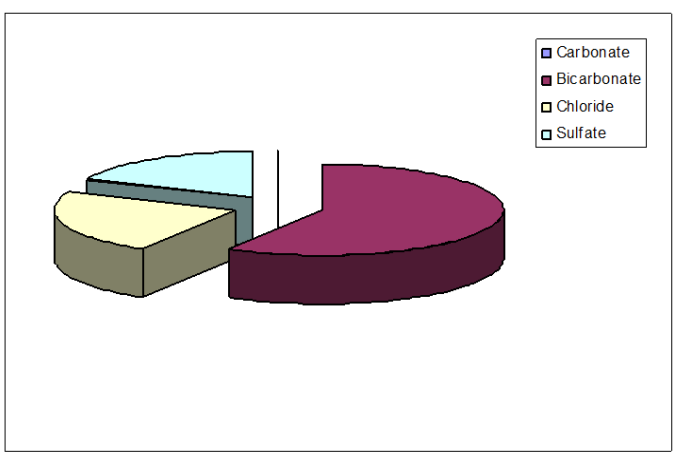

(a) anions

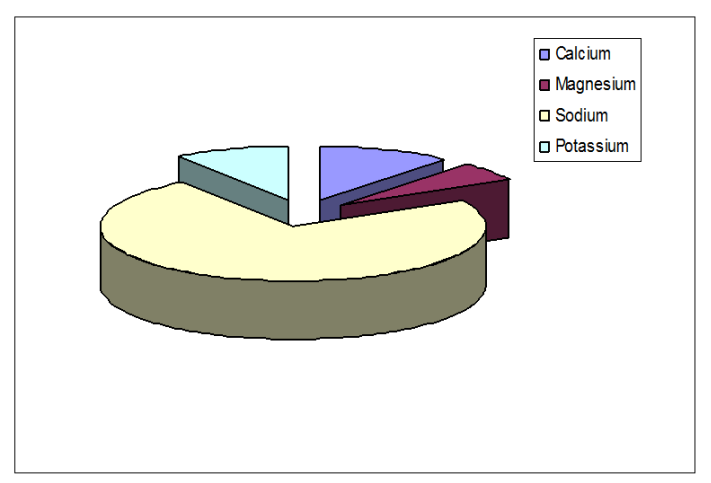

(b) cations

Figure 5. Pie chart showing major ions in groundwater. 


\subsection{Microbiological Analysis}

The results of the microbial analyses showed Total heterotrophic bacteria (THB) population ranging from Nil $3000 \mathrm{cfu} / \mathrm{ml}$ with mean of $109 \pm 570 \mathrm{cfu} / \mathrm{ml}$; while total coliform bacteria (TCB) values varied from Nil - 210
MPN/100ml with a mean of $8.6 \pm 43.6 \mathrm{MPN} / 100 \mathrm{ml}$. Faecal coliform bacteria (FCB) were not present in all the samples. The highest THB (3000 cfu/ml) and TCB (210 MPN/100ml) occurred at the Institute of Education (Figs. 6 and 7).

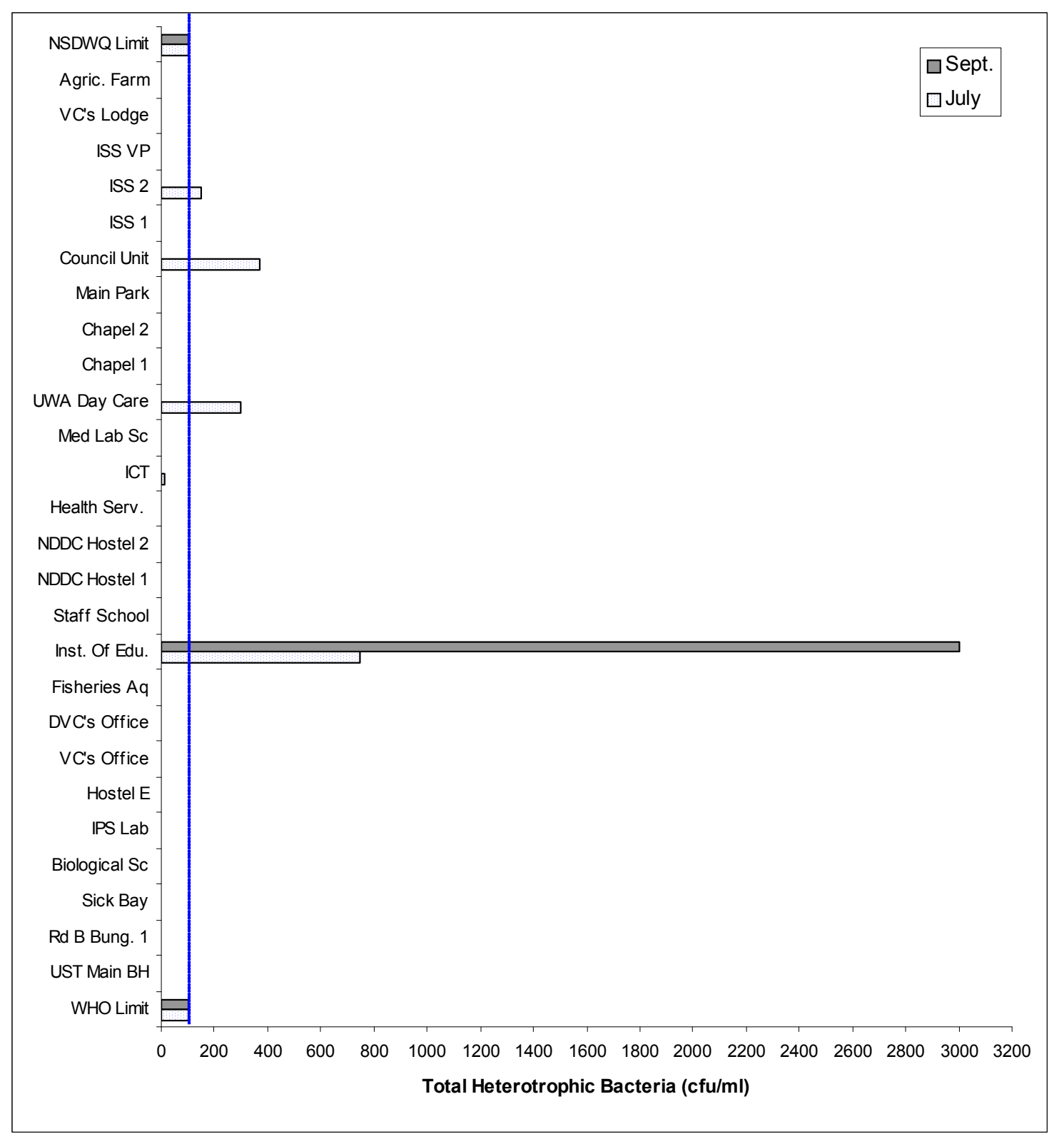

Figure 6. Total Heterotrophic Bacteria levels in RSUST groundwater July/Sept. 2013. 


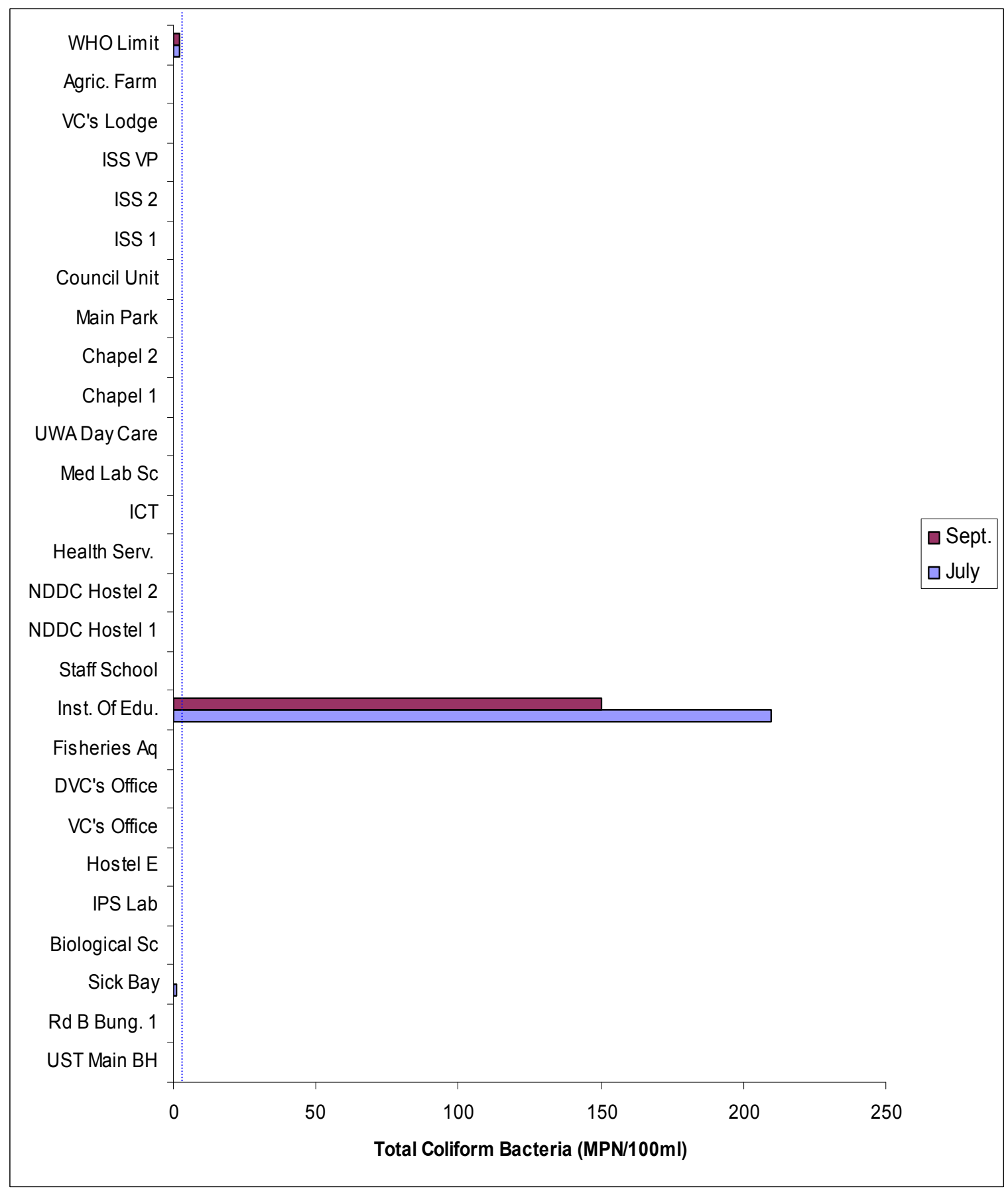

Figure 7. Total Coliform Bacteria levels in RSUST groundwater July/Sept. 2013.

\section{Discussions}

\subsection{Physico-Chemical Parameters pH}

The groundwater $\mathrm{pH}$, a measure of the hydrogen ion concentration depicted variation between acidic ( $\mathrm{pH} 4.09)$ and near neutral ( $\mathrm{pH}$ 6.77). This implies that the groundwater in the area is acidic. The low $\mathrm{pH}$ values (4.0-4.9) indicates that the aquifer may be associated with waters containing free acids derived from oxidizing Sulphide minerals of the parent bedrock materials. Those that have moderately low $\mathrm{pH}$ values (5.0-5.9) might be associated with small amount of mineral acids from Sulphide sources or with organic acids from decaying vegetation. The moderate $\mathrm{pH}$ values (6.396.77) which are slightly acidic in reaction occurred around ICT, Medical Lab. Sc. and Council Unit. This could be attributed to aquifer having high bicarbonate content [21].

It is observed in Fig 2 that all $(100 \%)$ of the water samples were below both national and international (SON and WHO) drinking water standards in July while only two stations (Medical Laboratory Sciences and Council Unit with $\mathrm{pH}$ of 6.73 and 6.77 respectively) representing $12.5 \%$ of the samples had $\mathrm{pH}$ values within acceptable limits in September. The remaining $87.5 \%$ of the samples were below the 
acceptable limit (pH 6.5-8.5).

At low $\mathrm{pH}$, dissolution of metals / absorption of toxic substances increase especially in high Carbonate and low Silicate soils. It promotes colour, affects alkalinity, TDS, $\mathrm{CO}_{2}$ absorption and Total Coliform presence [22], [23] - [24].

Prolonged intake of acidic water may predispose one to the dangers of acidosis, which according to Health Experts may lead to cancer or cardiovascular damage including the constriction of blood vessels and reduction in Oxygen supply even at mild levels [25]. It could also cause leaching of valuable minerals such as Calcium, Magnesium, Sodium and Calcium from the body.

Closely related to the $\mathrm{pH}$ is the alkalinity, which is a measure of the buffering capacity of the system. The recorded values were low $\left(2-8 \mathrm{mg} / \mathrm{l}\right.$ as $\left.\mathrm{CaCO}_{3}\right)$ and they are mostly due to bicarbonate contents.

Water hardness is another quality parameter that determines the use of water for drinking / domestic and industrial purposes. Simply put, the hardness is the capacity of water to lather on the application of soap and these increases with the softness of the water. The hardness level of $<0.1-34.6 \mathrm{mg} / 1$ as $\mathrm{CaCO}_{3}$ is within the $0-60 \mathrm{mg} / \mathrm{l}$ as $\mathrm{CaCO}_{3}$ classification of soft water. These hardness values are within the national and international limits. However, continued intake of soft water has been linked to cardiovascular diseases incidents [26], [27].

The TDS, which is a measure of all the dissolved substances in the water, was from 12 to $274 \mathrm{mg} / \mathrm{l}$. These values are within WHO $(600 \mathrm{mg} / \mathrm{l})$ and SON $(500 \mathrm{mg} / \mathrm{l})$ limits for drinking water. TDS correlated positively with conductivity, salinity, chloride, sulfate and nitrate. The levels of these parameters in the groundwater were within the stipulated standards (Table 1 ). All the conductivity values are within acceptable limit $(1000 \mu \mathrm{S} / \mathrm{cm}, \mathrm{SON}$ and $1200 \mu \mathrm{S} / \mathrm{cm}$ WHO). The TDS values ranged from $12 \mathrm{mg} / \mathrm{l}$ to $274 \mathrm{mg} / \mathrm{l}$ with mean of $67 \pm 67 \mathrm{mg} / \mathrm{l}$. These values are within both [18] and [19] potable water limits (Fig. 3).

The values obtained in the study for Conductivity, Salinity and TDS indicate that the ground water is fresh [21].

\subsection{Temperature and Turbidity}

The groundwater temperatures $\left(26.6-30.3^{\circ} \mathrm{C}\right)$ in July and September showed no significant difference indicating similarity in chemical behavior in the water characteristics within the study area. Turbidity values in both periods were $<0.01$ NTU indicating clear water devoid of suspended solids caused by clay, silt and other substances that enter boreholes from the aquifer or from the soil surface.

\subsection{Chloride, Sulphate, Phosphate and Nitrate}

The low Chloride concentrations $(<1.0-10.3 \mathrm{mg} / \mathrm{l})$ indicate that the aquifer recharge is high due to high rainfalls, it is not overdrawn and there are no contact with water of marine origin or leaching from the upper soil layers. RSUST is situated close to the mangrove swamp and overdrawn aquifer may give rise to saltwater intrusion.
Sulphate contents are attributable to the sedimentary basin of the Niger Delta region. The low Sulphate levels $(<1.0$ $15.5 \mathrm{mg} / \mathrm{l}$ ) could be related to the removal of Sulphate by Sulphur bacteria in the sub-surface water [28].

Phosphate concentrations are mostly less than $0.05 \mathrm{mg} / \mathrm{l}$; with the exception of water at Health Services station which had $1.90 \mathrm{mg} / \mathrm{l}$. This is indicative of absence of Phosphorus containing mineral apatite in the area. There is no potable water standard for Phosphorus by SON and WHO.

Nitrate levels in July $(0.30-4.30 \mathrm{mg} / \mathrm{l})$ are lower than those of September $(1.0-6.20 \mathrm{mg} / \mathrm{l})$. These Nitrate concentrations are within both [18] and [19] limits of $50 \mathrm{mg} / \mathrm{l}$. The higher levels in September could be due to leaching by percolating water that reached the groundwater fast because nitrate compounds are highly soluble [28].

\subsection{Microbial Analysis}

Total heterotrophic bacteria (THB) population in some boreholes exceeded WHO limit $(100 \mathrm{cfu} / \mathrm{ml})$ [18]. The boreholes $(15.4 \%)$ that exceeded stipulated WHO limit for THB were ISS2, UWA Day Care, Council Unit and Institute of Education. This implies that $15.4 \%$ of the boreholes studied had unacceptable THB values.

Total coliform bacteria (TCB) in the borehole at Institute of Education exceeded SON limit of 0-2 MPN/100ml [19]. The non-detection of faecal coliform bacteria in all the samples indicates no pollution with faecal matters.

The presence of microbes could be attributed to myriads of activities of microorganisms in the subsurface, shallow depth and water pressures not being high enough to deter microbial activity as many bacteria can survive under high osmotic pressures [29]. Also indigenous bacterial activity and active micro-flora exist in deep formations due to contamination by surface water seepage to an aquifer unprotected by relatively fine textured soil [30]. Droppings from birds into open water tanks also contributed to microbial contamination of the water. This could be the case of the Institute of Education borehole water which is exposed, located near the mangrove swamp forest and may be vulnerable to migration of contaminants from the creek water if the subsoil is coarse-textured.

\subsection{Water Characterization}

The groundwater in Rivers State University of Science and Technology has been classified based on the hydrogeochemical characteristics obtained in the Piper's diagram (Fig. 4).

There are five water types characterizing the aquifer and they include: $\mathrm{Ca}-\mathrm{HCO}_{3}^{-}, \mathrm{Na}-\mathrm{Cl}, \mathrm{Ca}-\mathrm{Mg}-\mathrm{Cl}^{-}, \mathrm{Ca}-\mathrm{Na}-$ $\mathrm{HCO}_{3}{ }^{-}$and $\mathrm{Na}-\mathrm{HCO}_{3}{ }^{-}$types. The order of occurrence were: $\mathrm{Na}-\mathrm{Cl}^{-}$type $(57.7 \%), \mathrm{Na}-\mathrm{Ca}-\mathrm{HCO}_{3}^{-}$type $(17.3 \%), \mathrm{HCO}_{3}{ }^{-}$ type $(13.5 \%), \mathrm{Na}-\mathrm{HCO}_{3}^{-}$type $(7.7 \%)$ and $\mathrm{Ca}-\mathrm{Mg}-\mathrm{Cl}^{-}$ type (3.8\%). The $\mathrm{Ca}-\mathrm{Cl}$ type was not observed in this study.

\subsection{Suitability for Irrigation}

Sodium gets to the aquifer from rainwater in coastal areas 
and / or dissolution of rock as rainwater percolates and the groundwater flows through the aquifer. As a result of effects of sodium on soil and plants; it is considered one major factor that governs the use of groundwater in irrigation [31], [32].

The suitability of groundwater for agricultural purposes (such as irrigation) is based on its Sodium Adsorption Ratio (SAR). The SAR was calculated using the formula (Richards, 1954):

$$
\mathrm{SAR}=\frac{\left(\mathrm{Na}^{+}\right)}{\sqrt{ }\left\{1 / 2\left[\left(\mathrm{Ca}^{2+}\right)+\left(\mathrm{Mg}^{2+}\right)\right]\right\}}
$$

Where, $\mathrm{Ca}^{2+}, \mathrm{Mg}^{2+}$ and $\mathrm{Na}^{+}$are in mili-eqivalent per litre (meq/l) concentration of the metals in the groundwater.

There are four sodium hazard classifications [33]: low/S1 (SAR <10), medium/S2 (SAR 10 - 18), high/S3 (SAR 18 26) and very high/S4 (SAR $>26)$.

Also, the soluble sodium percent (SSP) is another parameter used to indicate water that is suitable for irrigation. It was calculated from the formula:

$$
\mathrm{SSP}=\left[\mathrm{Na}^{+} /\left(\mathrm{Ca}^{+2}+\mathrm{Mg}^{+2}+\mathrm{Na}^{+}\right)\right] \times 100
$$

Where, $\mathrm{Ca}^{2+}, \mathrm{Mg}^{2+}$ and $\mathrm{Na}^{+}$are concentrations in meq/l. SSP values less or equal to 50 indicates good quality water while values greater than 50 are contrary and unsuitable for irrigation. The SAR and SSP values obtained for RSUST water samples are in Table 5.

\begin{tabular}{|c|c|c|c|c|c|}
\hline S/No. & Station / Location & SAR & SAR Status & SSP & $\begin{array}{l}\text { SSP } \\
\text { Status } \\
\end{array}$ \\
\hline 1. & UST Main BH & 1.903 & Excellent & 60.616 & Unsuitable \\
\hline 2. & Road B Bungalow 1 & 1.392 & Excellent & 49.734 & Good \\
\hline 3. & Sick Bay & 0.536 & Excellent & 49.734 & Good \\
\hline 4. & Biological Sc & 1.079 & Excellent & 50.755 & Unsuitable \\
\hline 5. & IPS Lab & 2.448 & Excellent & 50.094 & Fair \\
\hline 6. & Hostel E & 1.430 & Excellent & 44.531 & Good \\
\hline 7. & VC's Office & 1.078 & Excellent & 50.094 & Fair \\
\hline 8. & DVC's Office & 1.164 & Excellent & 33.417 & Good \\
\hline 9. & Fisheries Aq & 2.911 & Excellent & 49.734 & Good \\
\hline 10. & Inst. Of Education & 0.466 & Excellent & 50.094 & Fair \\
\hline 11. & Staff School & 1.759 & Excellent & 50.755 & Unsuitable \\
\hline 12. & NDDC Hostel 1 & 0.533 & Excellent & 50.755 & Unsuitable \\
\hline 13. & NDDC Hostel 2 & 1.011 & Excellent & 49.734 & Good \\
\hline 14. & Health Services & 0.268 & Excellent & 49.734 & Good \\
\hline 15. & ICT & 3.686 & Excellent & 50.094 & Fair \\
\hline 16. & Med Lab Sc & 0.648 & Excellent & 32.376 & Good \\
\hline 17. & UWA Day Care & 2.432 & Excellent & 50.755 & Unsuitable \\
\hline 18. & Chapel 1 & 0.535 & Excellent & 49.734 & Good \\
\hline 19. & Chapel 2 & 0.757 & Excellent & 49.734 & Good \\
\hline 20. & Main Park & 2.640 & Excellent & 28.922 & Good \\
\hline 21. & Council Unit & 0.002 & Excellent & 49.734 & Good \\
\hline 22. & ISS 1 & 4.246 & Excellent & 49.734 & Good \\
\hline 23. & ISS 2 & 4.325 & Excellent & 59.831 & Unsuitable \\
\hline 24. & ISS VP & 5.074 & Excellent & 67.625 & Unsuitable \\
\hline 25. & VC's Lodge & 1.558 & Excellent & 50.755 & Unsuitable \\
\hline 26. & Agric. Farm & 0.282 & Excellent & 49.734 & Good \\
\hline
\end{tabular}

Table 5. SAR and SSP values and status of RSUST water samples.
Based on the SAR all or $100 \%$ of the water samples are excellent for irrigation since the SAR ranged from 0.002 at Council Unit to 5.074 at ISS VP office. These values are below 10 and thus contain low sodium levels. From SSP standpoint; $53.8 \%$ of the samples are suitable for irrigation whose values ranged from 28.922 to 49.734 . Four that had SSP of 50.094 representing $15.4 \%$ are deemed as fair. The remaining $30.8 \%$ having SSP values that ranged from 50.755 to 67.625 are unsuitable for irrigation.

\section{Conclusions and Recommendations}

Based on the findings of this study the tap water within RSUST is fresh and soft with low to moderate dissolved solids. All the borehole water quality on Campus are not potable due to low $\mathrm{pH}$; in addition, borehole water at Council Unit, ISS, UWA and Institute of Education had high microbial count and therefore not suitable for drinking. The use of the water in its present state for aqua-culture might be detrimental to fishes. The water is suitable for irrigation and other purposes except drinking.

There is need to urgently commence treatment of water supplied to the University community and create awareness to educate people on the need to boil and/or filter the water prior to consumption.

\section{Acknowledgement}

The authors sincerely thank Professor B. B. Fakae, Vice Chancellor of University of Science and Technology, Port Harcourt for vision, encouragement and support; and the support and understanding of their colleagues.

\section{References}

[1] Uzochukwu, A. (2009). Sanitation Sector Status and Gap Analysis: Nigeria. In Global Sanitation Fund / Water Supply \& Sanitation Collaborative Council. p 15.

[2] EFSA, (2010). European Food Safety Authority. EFSA Panel on Dietetic Products, Nutrition, and Allergies (NDA); Scientific opinion of dietary reference values for water. EFSA Journal. 8(3);1459.

[3] Udoessien, E. I. (2003). Basic Principles of Environmental Science Etiliew Int. Publishers, Uyo, Akwa Ibom State, Nigeria. pp $27-63$.

[4] Majolagbe, A. O. Kasali, A A. and Ghaniyu, L O. (2011). Quality assessment of groundwater in the vicinity of dumpsites in Ifo and Lagos, Southern Nigeria. Advances in Applied Science Research, 2 (1), pp 289-299.

[5] Redmond, W. A. (2009) [DVD] Microsoft Corporation, USA. www.scribd.com/doc/52782458/waterpollution-and-the-law.

[6] Onyeagocha, A.C. (1980). Petrography and depositional environment of the Benin Formation. Jour. Min. Geol., Vol. 17. No. 2, pp. 147-151.

[7] Ganoulis, J. (1994). Risk Analysis of Water Pollution: Probabilities and Fuzzy Sets. VCH, Weinheim, Oxford, NY, $306 \mathrm{pp}$. 
[8] Back, W (1966). Hydrochemical facies and ground-water flow patterns in northern part of Atlantic Coastal Plain. Hydrology of aquifer systems: U.S. Geol. Survey Prof. Paper 498-A, 42.

[9] Nwankwoala, H. O. and Udom, G. J. (2011). Hydrogeochemical Evaluation of Groundwater in Parts of Eastern Niger Delta, Nigeria. Journal of Academic and Applied Studies, Vol. 1, No. 2, pp 33 - 58.

[10] Subramani, T., I. Elango and S.R. Damodarasamy (2005). Groundwater quality and its suitability for drinking and agricultural use in chithar river basin, Tamil nadu, India. Environ. Geol. 47, 1099-1110.

[11] Nyanganji, J. K., Abdullahi, J. and Noma, I. U. S. (2011) Groundwater quality and related water borne diseases in Dass Town, Bauchi State, Nigeria. Journal of Environmental Issues and Agriculture in Developing Countries, Vol. 3, No. 2, pp 133-148.

[12] Sandhyarami, N. (2009). Groundwater Pollution. buzzle.com.http://www.buzzle.com/articles/ groundwaterpollution.

[13] N.M.S. (1998). Nigerian Meteorological Services, pp. 1-10.

[14] Simpson, A. (1954). The Nigerian coal fields, the geology of parts of Onitsha, Owerri and

[15] Ideriah, T.J.K. (2003). Levels of heavy metals and physicochemical parameters in soils, leachates, water and sediments around selected municipal waste dumpsites in Port Harcourt and Environs, Nigeria. Ph.D degree thesis in Rivers State University of Science and Technology Port Harcourt, pp. 40-43.

[16] APHA (1995). Standard Methods for the Examination of Water and Wastewater, 18th ed. APHA-AWWA-WPCF, Washington DC.

[17] ASTM (1999). American Society for Testing \& Material (International), Bar Harbor Drive, P O Box C700, West Conshohocken, PA 19428-2959, USA.

[18] WHO (2006) World Health Organization Guidelines for Drinking-water Quality. First Addendum to Third Edition, Vol. 1, Recommendations. Geneva.

[19] SON (2007). Nigerian Standard for Drinking Water Quality. Lagos: Standard Organization of Nigeria.
[20] Piper, A M (1944) A graphic procedure in geochemical interpretation of water analyses. American Geophysical Union Transactions 25:914-923.

[21] Davis, S. N. and Dewest, R. J. M. (1966). Hydrology. John Wiley and Sons, Inc. London.

[22] Gerard. K. (1998). Environmental Engineering, Irwin/ McGraw-Hill Book Company, Singapore pp.456.

[23] Ming-HO, YU (2001). Environmental Toxicology, Impact of Environmental Toxicants on Living Systems. Lewis Publishers, London. pp.49, 151.

[24] Lecherallein, M.W., Welch, N.J and Smith, D.B (1996). Fullscale study of Factors related to Coliform regrowth in Drinking Water. Applied and Environmental Microbiological Journal 1 (62): p.2201.

[25] Ogundipe, S and Obinna, C (2008). "Safety of Table Water goes beyond the bottle" In: Good Health Weekly, Vanguard Newspapers Tuesday, May 20, 2008 p.42. River Basin. J. Hydrological Sciences, London.

[26] Miroslav, R. and Vladimir, N.B. (1999). Practical Environmental Analysis, Royal Society of Chemistry, U.K pp. $152,175$.

[27] Encyclopedia of Chemical Technology (1970). Second Edition Vol. 21, p 693.

[28] McNeely, R. N. Nemimanis, V.P. Dwyer, (1979). Water Quality Source book. A Guide to water Quality Parameter. Inland waters Directorate, water Quality Branch, Ottawa, Canada pp.

[29] Bower, H. (1978). Groundwater Hydrology, International Student Edition. McGraw-Hill Kogakusha, Ltd. Tokyo

[30] Romero, J. C. (1970). The movement of bacteria and viruses through porous media. Ground Water 8 (2): 37-49.

[31] USDA, (1954). U.S. Department of Agriculture. Diagnosis and Improvement of Saline and Alkali Soils Handbook 60, Washington D.C.

[32] Offodili, M E (2002) Groundwater study and development in Nigeria. Mecon Geology Eng. Services Ltd. Jos; 453 pages.

[33] Richards, L. A. (1954) Diagnosis and Improvement of Saline and Alkali Soils Agric Handbook 60, USDA and IBH Publishing Company Ltd., New Delhi, India, pp 98-99. 